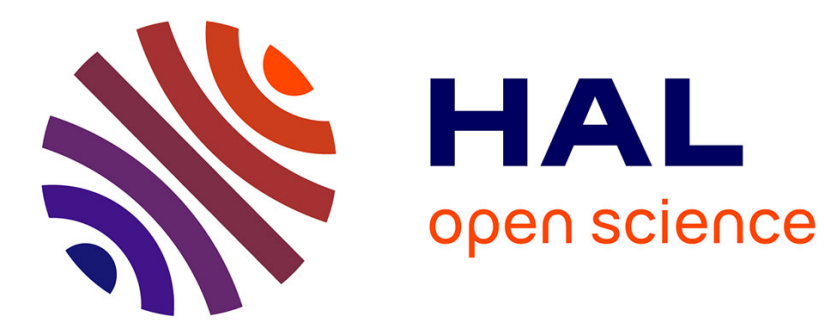

\title{
Validity of a kinetic fouling model for heat-treatment of whole milk
}

P de Jong, R Waalewijn, Hjlj van Der Linden

\section{To cite this version:}

P de Jong, R Waalewijn, Hjlj van Der Linden. Validity of a kinetic fouling model for heat-treatment of whole milk. Le Lait, 1993, 73 (3), pp.293-302. hal-00929341

\section{HAL Id: hal-00929341 \\ https://hal.science/hal-00929341}

Submitted on 1 Jan 1993

HAL is a multi-disciplinary open access archive for the deposit and dissemination of scientific research documents, whether they are published or not. The documents may come from teaching and research institutions in France or abroad, or from public or private research centers.
L'archive ouverte pluridisciplinaire $\mathbf{H A L}$, est destinée au dépôt et à la diffusion de documents scientifiques de niveau recherche, publiés ou non, émanant des établissements d'enseignement et de recherche français ou étrangers, des laboratoires publics ou privés. 


\title{
Original article
}

\section{Validity of a kinetic fouling model for heat-treatment of whole milk}

\author{
P De Jong, R Waalewijn, HJLJ Van Der Linden
}

Department of Process Engineering, Netherlands Institute for Dairy Research (NIZO), PO Box 20,6710 BA Ede, The Netherlands

(Received 4 November 1992; accepted 13 January 1993)

\begin{abstract}
Summary - The suitability of a reaction kinetic fouling model was investigated for fouling of heat exchanger surfaces by whole milk. Experiments were carried out on a plate heat exchanger by applying different temperature-time combinations in the temperature range from 70 to $130^{\circ} \mathrm{C}$. The denaturation of whey proteins was measured by high performance gel permeation chromatography and the amount and composition of deposits on the plates of the heat exchanger was determined. The kinetic fouling model turned out to be valid for estimations of the relative deposit distribution in heat treatment equipment for temperatures up to $115^{\circ} \mathrm{C}$. The absolute fouling level increased strongly with aging of the milk.
\end{abstract}

fouling / milk / modelling / heat treatment / whey protein denaturation

Résumé - Validité d'un modèle d'encrassement cinétique pour le traitement thermique du lait entier. La validité d'un modèle d'encrassement cinétique réactionnel pour une estimation de l'encrassement par le lait entier des surfaces d'un échangeur de chaleur a été examinée. Des expériences ont été faites sur un échangeur de chaleur à plaques en appliquant différentes combinaisons de température-temps dans la plage de températures de 70 à $130^{\circ} \mathrm{C}$. La dénaturation des protéines solubles a été mesurée par chromatographie par perméation de gel à haute performance; la quantité et la composition des dépôts sur les plaques de l'échangeur de chaleur ont été déterminées. Le modèle d'encrassement cinétique s'est révélé valable pour des estimations de la distribution relative des dépôts dans le dispositif de traitement thermique pour des températures atteignant $115^{\circ} \mathrm{C}$. Le niveau d'encrassement absolu augmentait fortement proportionnellement au vieillissement du lait.

encrassement / lait / modélisation / traitement thermique / dénaturation des protéines solubles 


\section{INTRODUCTION}

Fouling is a very complex phenomenon in design and operation of heat treatment equipment in the dairy industry. The absolute fouling level is not only product-related but also controlled by aging of milk (Jeurnink, 1991) and seasonal influences (Grandison, 1988). The relative deposit distribution, however, can be related to heat-induced transformations in the milk (De Jong et al, 1992).

In previous work a kinetic fouling model has been proposed, based on a reactor engineering approach with experimental verification by heat treatment of skim milk (De Jong et al, 1992). The main mechanism was found to be a reaction-controlled adsorption of unfolded $\beta$-lactoglobulin ( $\beta$ $\mathrm{lg}$ ) at an external heat transfer surface. This model turned out to be an accurate tool for estimating the deposit distribution by skim milk in a heat exchanger up to $110^{\circ} \mathrm{C}$. The literature on the denaturation kinetics of $\beta$-lg has concentrated mostly on the kinetics in skim milk rather than on the kinetics in whole milk. De Wit and Klarenbeek (1989) established the aggregation kinetics for a small temperature range and demonstrated that the kinetic data in whole milk differ from those in skim milk. Since the necessary kinetic data to determine the concentration of unfolded $\beta$ - $\mathrm{lg}$ in whole milk are not available, the specific fouling model parameters for whole milk cannot be established.

In this paper the suitability of the available fouling model for skim milk is investigated for fouling of heat exchanger surfaces by whole milk. Generally the local fouling process can be considered as a heterogeneous adsorption reaction of milk constituents at the surface with mass transfer and reaction in series: transport in the boundary layer and the reaction process at the deposit surface. The main mechanism in the fouling process of skim milk is a reaction-controlled adsorption of unfolded $\beta$-lg which is described by the following equations (De Jong et al, 1992).

Denaturation of $\beta$-lg:

$$
\begin{aligned}
& \frac{d C_{N}}{d t}=-k_{p} C_{N}^{P} \text { (unfolding) } \\
& \frac{d C_{A}}{d t}=k_{q} C_{U} \text { (aggregation) } \\
& \frac{d C_{U}}{d t}=k_{p} C_{N}^{P}-k_{q} C_{U}^{g}
\end{aligned}
$$

Fouling:

$$
J_{F}=k_{n}{ }^{\prime \prime} C_{U}^{n}
$$

Temperature dependence:

$$
k=k_{0} \exp \left(-E_{a} / R T\right)
$$

The developed model gives good agreement with the experimental data of skim milk up to bulk temperatures of $110^{\circ} \mathrm{C}$. To get a more reliable description of the fouling process, the kinetic parameters were refined with new regression analyses relating $k_{n}$ to the deposit surface temperature instead of the bulk temperature. The kinetic data are given in table I.

\section{MATERIAL AND METHODS}

\section{Experimental set-up}

Two sequences of experiments with preheated whole milk $\left(10 \mathrm{~s}\right.$ at $\left.65^{\circ} \mathrm{C}\right)$ were carried out during operating times of $6 \mathrm{~h}$ with a plate heat exchanger (Alfa-laval, type H7-RC). To avoid er- 
Table I. Kinetic data of the denaturation of $\beta-\mathrm{lg}$ and $\alpha$-la for skim milk and whole milk and the fouling (adsorption) model for skim milk.

Données cinétiques de la dénaturation de $\beta$-lg et d' $\alpha$-la pour le lait écrémé et le lait entier et du modèle d'encrassement (d'adsorption) pour le lait écrémé.

\begin{tabular}{|c|c|c|c|c|c|c|c|}
\hline $\begin{array}{l}\text { Component } \\
\text { Product }\end{array}$ & Mechanism & $\begin{array}{l}\text { Temp } \\
\text { range } \\
\left({ }^{\circ} \mathrm{C}\right)\end{array}$ & Order & $\begin{array}{l}E_{a} \\
{[\mathrm{~kJ} / \mathrm{mol}]}\end{array}$ & $\ln k_{0}$ & $r$ & Ref \\
\hline$\beta-\lg / S M$ & Unfolding & $70-90$ & 1.0 & 261 & 86.41 & - & De Wit \\
\hline$\beta-I g / S M$ & Aggregation & $70-90$ & 2.0 & 312 & 99.32 & 0.996 & De Wit* \\
\hline$\beta-\lg / S M$ & Aggregation & $90-150$ & 2.0 & 56 & 14.42 & 0.999 & Dannenberg \\
\hline$\beta-\lg / S M$ & Aggregation & $75-85$ & 1.8 & 374 & 120.64 & - & De Wit \\
\hline$\alpha-\mathrm{la} / \mathrm{SM}$ & Aggregation & $70-80$ & 1.0 & 269 & 84.92 & 0.999 & Dannenberg \\
\hline $\begin{array}{l}\alpha \text {-la/SM } \\
\text { Deposit/SM }\end{array}$ & $\begin{array}{l}\text { Aggregation } \\
\text { Adsorption }\end{array}$ & $\begin{array}{l}80-150 \\
80-115\end{array}$ & $\begin{array}{l}1.0 \\
1.2\end{array}$ & $\begin{array}{l}69 \\
45\end{array}$ & $\begin{array}{r}16.95 \\
-0.68\end{array}$ & $\begin{array}{l}0.999 \\
0.963\end{array}$ & $\begin{array}{l}\text { Dannenberg } \\
\text { De Jong* }\end{array}$ \\
\hline
\end{tabular}

- Extracted from experimental results; $S M=$ skim milk; $W M=$ whole milk.

- Tirés de résultats expérimentaux; $S M=$ lait écrémé; $W M=$ lait entier.

rors in the determination of protein denaturation, the milk was not homogenized (homogenized milk causes a turbid supernatant). The milk used in the first experiment of a sequence was $\approx$ $3 \mathrm{~d}$ stored at $5^{\circ} \mathrm{C}$. Sequence $1(\exp 4,5,6)$ was carried out 2 months earlier than sequence 2 (exp 1, 2, 3).

Table II summarizes a survey of the process conditions during the experiments. The mass flow rate of the milk was $2300 \mathrm{~kg} / \mathrm{h}$ ( $R e \approx$ 12000 ). With an additional holder section and different temperature settings, 6 combinations of temperature and time were realized. The arrangement of the sections of the experimental set-up is given in figure 1. A more detailed description of the equipment has been reported in a previous study (De Jong et al, 1992).

\section{Analyses}

The aggregation of $\beta-\mathrm{lg}$ and $\alpha$-lactalbumin ( $\alpha-\mathrm{la}$ ) was determined at four sample points (see fig 1), twice in each experiment. The degree of aggregation was measured by high performance gel permeation chromatography (HP-GPC) at
pH 6.7 as described by De Wit and Klarenbeek (1989).

At the end of an experiment the heat treatment equipment was rinsed with water and dismantled. The holder and the heater were visually inspected. Each plate of the preheater and the regenerative section was mechanically cleaned with 16 I of a 1 vol\% sodium hydroxide solution. The amount of deposits at the upstream side of the regenerative section was negligible ( $<5 \%$ of the total). To analyze the quantity and the composition of the deposits on each plate, a sample was taken from the cleaning agent. The fouling rate in the heater was estimated by comparing visually the amount of deposits in the heater with the final plate of the regenerative section.

The samples were analyzed by the following determinations: calcium; chemical oxygen demand (COD) according to NEN 6633 (1990); Kjeldahl (nitrogen quantity) according to NEN 3198 (1984).

The concentrations of protein and fat are given by:

$$
C_{\text {protein }}=C_{N 2} / 0.157
$$


Table II. Process conditions of the experiments.

Conditions de déroulement des expériences.

Experiment

$\begin{array}{llllll}1 & 2 & 3 & 4 & 5 & 6\end{array}$

\begin{tabular}{|c|c|c|c|c|c|c|}
\hline $\begin{array}{l}\text { Preheater } \\
\mathrm{T}_{\text {inlet }}\left[{ }^{\circ} \mathrm{C}\right]\end{array}$ & 44.4 & 44.8 & 44.6 & 44.8 & 44.9 & 41.4 \\
\hline $\mathrm{T}_{\text {outlet }}\left[{ }^{\circ} \mathrm{C}\right]$ & 85.1 & 85.1 & 85.2 & 85.2 & 85.2 & 85.1 \\
\hline$T[S]$ & 14.1 & 14.1 & 14.1 & 14.1 & 14.1 & 14.1 \\
\hline Holder & & * & $*$ & $*$ & $*$ & \\
\hline $\mathrm{T}_{\text {inlet }}\left[{ }^{\circ} \mathrm{C}\right]$ & - & 85.1 & 85.2 & 85.2 & 85.2 & - \\
\hline $\mathrm{T}_{\text {outlet }}\left[{ }^{\circ} \mathrm{C}\right]$ & - & 85.1 & 84.0 & 83.8 & 83.9 & - \\
\hline$T[\mathrm{~S}]$ & - & 103.4 & 132.7 & 132.7 & 132.7 & - \\
\hline $\begin{array}{l}\text { Regeneration } \\
T_{\text {Tinet }}\left[{ }^{\circ} \mathrm{C}\right]\end{array}$ & 84.9 & 86.8 & 84.0 & 83.8 & 83.9 & 84.9 \\
\hline $\mathrm{T}_{\text {outlet }}\left[{ }^{\circ} \mathrm{C}\right]$ & 116.5 & 116.9 & 116.6 & 116.7 & 107.8 & 124.1 \\
\hline$T$ [S] & 27.8 & 27.8 & 27.8 & 27.8 & 27.9 & 27.8 \\
\hline $\begin{array}{l}\text { Heater } \\
\mathrm{T}_{\text {inlet }}\left[{ }^{\circ} \mathrm{C}\right]\end{array}$ & 116.5 & 116.9 & 116.6 & 116.7 & 107.8 & 124.1 \\
\hline $\mathrm{T}_{\text {outlet }}\left[{ }^{\circ} \mathrm{C}\right]$ & 121.7 & 121.9 & 122.0 & 122.0 & 111.7 & 132.1 \\
\hline$T$ [S] & 13.8 & 13.8 & 13.8 & 13.8 & 13.9 & 13.8 \\
\hline
\end{tabular}

- Stirred tank; ** holder tube.

" Tank agité; "* Tube de calibrage.

$$
C_{\text {fat }}=\left(\mathrm{CO}_{2}-1.27 C_{\text {protein }}\right) / 2.96
$$

The deposition rate of each component follows from:

$$
J_{\text {comp }}=\frac{V_{\mathrm{NaOH}}}{A_{\text {plate }} t_{p}} C_{\text {comp }}
$$

It is assumed that the induction time (time during which no fouling occurs) is negligible in comparison with the run time (Fryer, 1989) and that the deposits consist mainly of protein and fat (Lalande and René, 1989).

\section{RESULTS AND DISCUSSION}

\section{Denaturation of $\beta-1 g$ and $\alpha-1 a$}

The effect of time and temperature of the heat treatment on the rates of denaturation of $\beta$ - lg and $\alpha$-la is shown in table III. The accuracy of the HP-GPC method was not sufficient to measure aggregation levels $>90 \%$. Consequently the aggregation of $\beta$ Ig for the sample point after the regenerative section could not be determined. The 


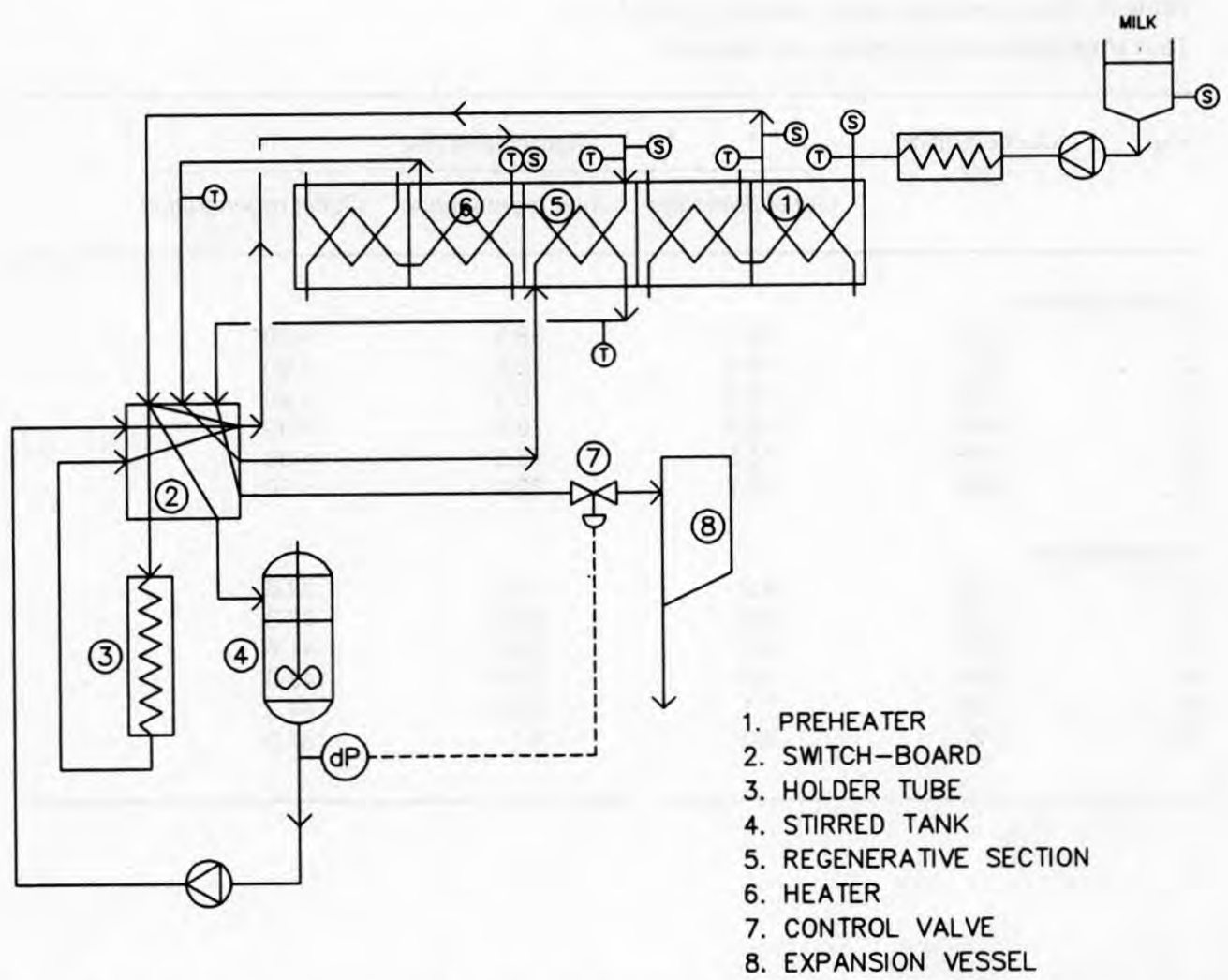

Fig 1. Arrangement of the experimental heat exchanger plant; $T$ : thermocouples; $S$ : sample points, $\mathrm{dP}$ : pressure measurement.

Arrangement du dispositif échangeur de chaleur expérimental; $T$ : thermocouples, $S$ : dispositif de prélèvement d'échantillons pour prélever du lait, $d P$ : mesure de la pression.

increase of the aggregation level of the samples taken before and after the regenerative section is due to the application of an additional holder section (exp 2-5) and to higher temperatures in the regenerative section (exp 6) respectively.

The measured quantities of aggregated $\beta-\lg$ and $\alpha$-la were compared with computer simulations based on reaction kinetics from the literature (see table I, lines 4-6). The computer program used solved the reaction rate equations [1], [2], [3] and [5] as a function of time, temperature and heating rate. In figure 2 the experimental values are plotted against the values calculated with the computer program. In general the experimental values are higher than the calculated ones. This can be partly explained by aggregation proceeding for $\approx 10-30 \mathrm{~s}$ during sampling at relatively high temperatures. This results in $2-10 \%$ extra aggregation. Furthermore, it is remarkable that the calculations based on the kinetics of $\alpha$-la in skim milk are in rather good agreement with the measured values in whole milk. 
Table III. Measured aggregation rates of $\beta-\mathrm{lg}$ and $\alpha-\mathrm{la}$.

Taux d'agrégation de $\beta$-lg et de $\alpha$-la mesurés.

\begin{tabular}{lll}
\hline \multirow{2}{*}{$\begin{array}{c}\text { Exp } \\
(g / l)\end{array}$} & \multicolumn{2}{c}{ Aggregated $(\%)$} \\
\cline { 3 - 4 } & Outlet preheater & Inlet regeneration Outlet regeneration
\end{tabular}

$\beta$-Lactoglobulin

$1 \quad 3.75$

$2 \quad 3.61$

$3 \quad 3.65$

$4 \quad 4.06$

$5 \quad 4.06$

$6 \quad 4.06$

$\alpha$-Lactalbumin

$\begin{array}{ll}1 & 1.23 \\ 2 & 1.19 \\ 3 & 1.20 \\ 4 & 1.30 \\ 5 & 1.29 \\ 6 & 1.27\end{array}$

26.7

19.5

19.0

12.9

14.5

15.7

6.2

3.6

4.0

0.4

1.1

2.3

$\begin{array}{ll}38.9 & >90 \\ 72.6 & >90 \\ 75.9 & >90 \\ 75.9 & >90 \\ 76.0 & >90 \\ 32.4 & >90\end{array}$

10.2

26.0

28.3

24.4

25.4

6.1
33.6

38.3

41.6

43.6

44.3

37.3

\section{Composition of the deposit layer}

The determined compositions of the deposit layer are summarized in table IV. From each experiment the mean percentage of protein, calcium and fat is spread over 3 temperature ranges.

Between 80 and $110^{\circ} \mathrm{C}$ the deposits turn out to be largely the Type $A$ deposit as classified by Burton (1968), which consists of $>50 \%$ protein. This affirms the key role of whey proteins in the process, especially in this temperature range (De Jong et al, 1992). Both at temperatures $<80^{\circ} \mathrm{C}$ and $>110^{\circ} \mathrm{C}$, the protein content decreases and the calcium content increases, which indicates a growing role of calcium phosphate precipitation (Burton, 1988).

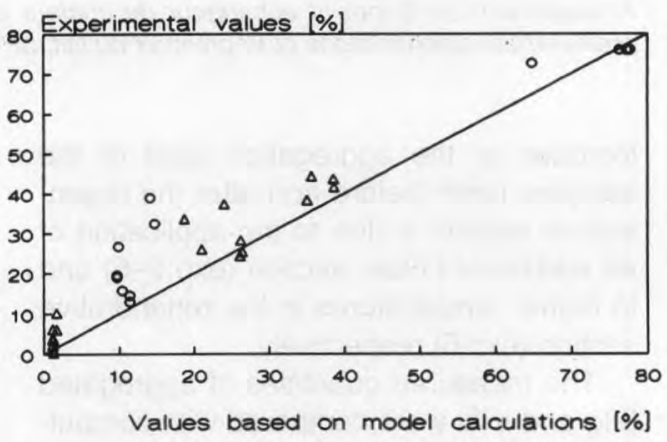

Fig 2. Measured amounts of aggregated $\beta-\lg (O)$ and $\alpha-$ la $(\Delta)$ plotted against calculated values.

Quantités mesurées de $\beta-\lg (O)$ et d' $\alpha$-la ( $(\Delta)$ agrégées, comparées aux valeurs calculées. 
Table IV. Determined composition of the deposit layer.

Composition déterminée de la couche de dépôts.

\begin{tabular}{|c|c|c|c|c|c|c|c|}
\hline \multirow{2}{*}{$\begin{array}{l}\text { Temperature } \\
\text { range } \\
\left({ }^{\circ} \mathrm{C}\right)\end{array}$} & \multirow[t]{2}{*}{ Component } & \multicolumn{6}{|c|}{ Experiment } \\
\hline & & 1 & 2 & 3 & 4 & 5 & 6 \\
\hline \multirow[t]{2}{*}{$60-80$} & $\begin{array}{l}\text { Protein }(\%) \\
\mathrm{Ca}_{3}\left(\mathrm{PO}_{4}\right)_{2}(\%)^{*}\end{array}$ & $\begin{array}{l}39.1 \\
55.4\end{array}$ & $\begin{array}{l}34.9 \\
60.7\end{array}$ & $\begin{array}{l}40.0 \\
57.5\end{array}$ & $\begin{array}{l}36.7 \\
60.2\end{array}$ & $\begin{array}{l}42.1 \\
53.7\end{array}$ & $\begin{array}{l}41.3 \\
50.9\end{array}$ \\
\hline & Fat (\%) & 5.5 & 4.4 & 2.5 & 3.0 & 4.2 & 7.8 \\
\hline \multirow[t]{2}{*}{$80-110$} & $\begin{array}{l}\text { Protein (\%) } \\
\mathrm{Ca}_{3}\left(\mathrm{PO}_{4}\right)_{2}(\%)\end{array}$ & $\begin{array}{l}50.8 \\
41.4\end{array}$ & $\begin{array}{l}50.7 \\
38.9\end{array}$ & $\begin{array}{l}54.6 \\
31.1\end{array}$ & $\begin{array}{l}52.7 \\
37.5\end{array}$ & $\begin{array}{l}58.4 \\
31.8\end{array}$ & $\begin{array}{l}67.3 \\
14.2\end{array}$ \\
\hline & Fat (\%) & 7.8 & 10.4 & 14.3 & 9.8 & 9.8 & 18.6 \\
\hline \multirow[t]{2}{*}{$110-120$} & $\begin{array}{l}\text { Protein }(\%) \\
\mathrm{Ca}_{3}\left(\mathrm{PO}_{4}\right)_{2}(\%)\end{array}$ & $\begin{array}{l}47.9 \\
43.5\end{array}$ & $\begin{array}{l}48.7 \\
40.2\end{array}$ & $\begin{array}{l}42.0 \\
46.2\end{array}$ & $\begin{array}{l}40.1 \\
45.3\end{array}$ & $\begin{array}{l}- \\
-\end{array}$ & $\begin{array}{l}59.0 \\
29.6\end{array}$ \\
\hline & Fat $(\%)$ & 8.6 & 11.1 & 11.8 & 14.6 & - & 11.4 \\
\hline
\end{tabular}

- Assuming that calcium precipitates as $\mathrm{Ca}_{3}\left(\mathrm{PO}_{4}\right)_{2}$ (Jeurnink, 1989).

\section{Fouling level}

The increasing amount of deposits measured in the preheater under the same process conditions (see table II) and with the same milk charge, indicates the effect of aging milk. Figure 3 shows the relation between the average fouling rate in the preheater and the age of milk. The significant increase of the fouling level by a factor of 3 to 6 can probably be explained by the action of proteolytic enzymes, which results in a decreasing heat stability of the casein micelles and additional protein deposition (Jeurnink, 1991). It is clear that these results affirm the proposition that the absolute fouling level cannot be predicted by a fouling model based on heat-induced transformations of milk constituents alone.

Fig 3. Effect of milk aging on the fouling level in the preheater.

Effet du vieillissement du lait sur le niveau d'adsorption dans le dispositif de préchauffage.

\section{Model evaluations}

Figures $4 a-f$ show the measured and estimated deposition rates in the preheater and regenerative section and in the heater for the different experiments. To evaluate the fouling model developed for skim milk, the values calculated by the model are plotted in the figures, within the temperature limitations given in table I. To eliminate the effect of the alternating fouling level, for each experiment the kinetic parameter $k^{\prime \prime}{ }_{0}$ has been fitted.

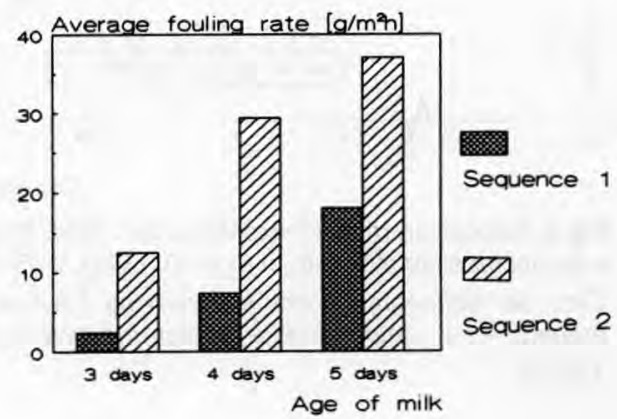


The first maximum in deposition rate was found at the end of the preheater. In agreement with previous results of De Jong et al (1992), a second maximum was measured at the end of the regenerative section. Depending on the holding time, the magnitude of this maximum decreases
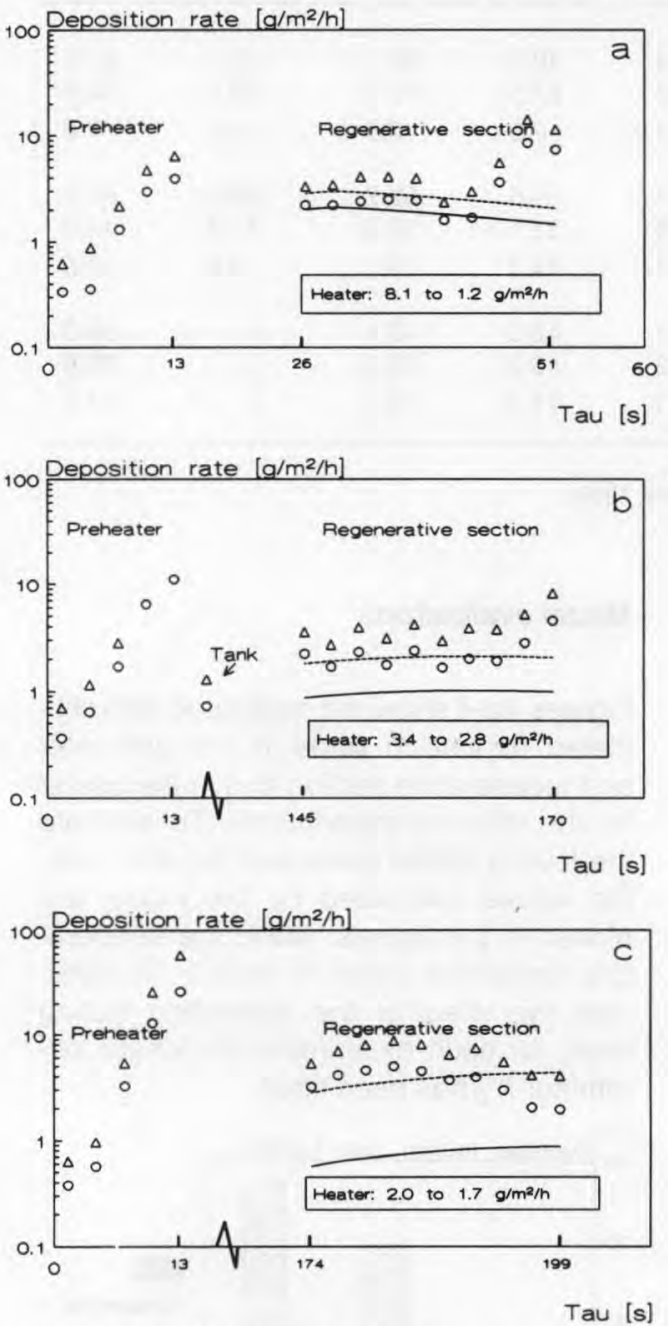

(exp 2,4$)$ or disappears completely $(\exp 3$ $5)$. Higher temperatures in the regenerative section (exp 6) did move the second maximum upstream. At temperatures above $120^{\circ} \mathrm{C}$, a third maximum arose in the heater.
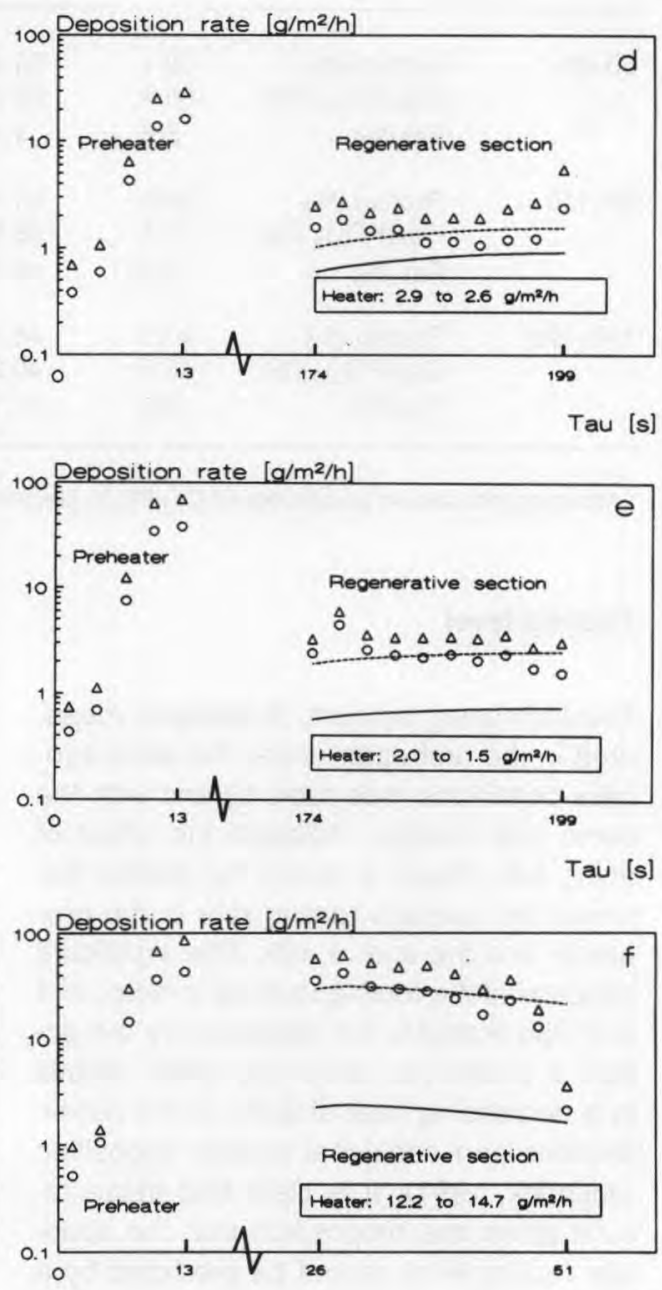

Tau $[s]$

Fig 4. Deposition rates of experiments $1-6(a-f) ; O=$ protein, $\Delta=$ total, $-=$ model for skim milk; - - $=$ model for skim milk with $\ln \mathrm{k}_{0}=-0.33$ (a), 0.05 (b), 0.91 (c), -0.15 (d), 0.53 (e), 1.90 (f).

Taux de sédimentation des expériences 1 à 6 (a à $f$ ); $O=$ protéine, $\Delta=$ total, $-=$ modèle pour lait écrémé, - - = modèle pour lait écrémé avec In $k_{0}=-0,33$ (a), 0,05 (b), 0,91 (c), $-0,15$ (d), 0,53 (e), $1,90(f)$. 
The maxima in the local deposition rate can be largely explained by use of the fouling model presented. From equations [4] and [5] it follows that the deposition rate increases with both the concentration of unfolded $\beta-\lg$ and the temperature. In the preheater the temperature of the milk rises and native $\beta-\mathrm{lg}$ transforms into unfolded $\beta$ $\mathrm{lg}$, resulting in an increase of the deposition rate with residence time (see figs $4 a-$ f). The function of an additional holder is to decrease the downstream concentration of unfolded $\beta-\mathrm{lg}$ by aggregation. In this way the deposition rate in the regenerative section will be reduced. At the beginning of the regenerative section the aggregation of unfolded $\beta-\mathrm{lg}$ dominates and consequently, the concentration of unfolded $\beta$-lg decreases. The rise in temperature and the decreasing concentration of unfolded $\beta$-lg results in an apparently stabilized and nearly constant deposition rate. When the temperature influence becomes predominant, the deposition rate will rise again. The third maximum $>120^{\circ} \mathrm{C}$ is probably due to other

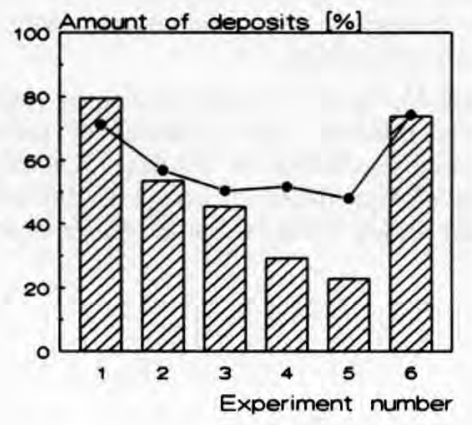

EDA Experiment

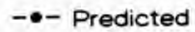

Fig 5. The amount of deposits in the regenerative section as a percentage of the total amount in the preheater and regenerative section.

Quantité de dépôts dans la section régénérative traduite en pourcentage de la quantité totale dans le dispositif de préchauffage et la section régénérative. fouling mechanisms (Burton, 1988) or may be governed by the denaturation of $\alpha$-la.

The suitability of the fouling model developed for skim milk for predicting deposit distributions caused by whole milk, is demonstrated in figure 5 . It appears that the effect of the combination of temperature and time on the amount of deposits in the regenerative section can be estimated very well.

\section{CONCLUSIONS}

The available fouling model for skim milk can also be used for predicting the deposit distribution in heat treatment equipment due to fouling by whole milk. Consequent$l y$, the model provides for the design of heating equipment and the determination of the optimal combination of temperature and time resulting in minimal fouling of equipment. Besides the effect of heatinduced protein transformations, the local fouling level is strongly influenced by the age of the milk.

\section{NOTATION}

$A$ : area $\left(\mathrm{m}^{2}\right)$

$C$ : concentration $\left(\mathrm{kg}^{\prime} \mathrm{m}^{-3}\right)$

$C_{A}$ : concentration of aggregated $\beta-\mathrm{lg}$ $\left(\mathrm{kg} \cdot \mathrm{m}^{-3}\right)$

$C_{N}$ : concentration of native $\beta-\mathrm{lg}\left(\mathrm{kg} \cdot \mathrm{m}^{-3}\right)$

$C_{U}$ : concentration of unfolded $\beta-\mathrm{lg}\left(\mathrm{kg} \cdot \mathrm{m}^{-3}\right)$

$E_{a}$ : activation energy $\left(\mathrm{J} \cdot \mathrm{mol}^{-1}\right)$

$J_{F}$ : deposition rate of milk constituents $\left(\mathrm{kg} \cdot \mathrm{m}^{-2} \cdot \mathrm{s}^{-1}\right)$

$k$ : reaction rate constant $\left(\mathrm{m}^{3(n-1)} \cdot \mathrm{kg}^{(1-}\right.$ n). $s^{-1}$ )

$k_{0}$ : pre-exponential factor $\left(\mathrm{m}^{3(\mathrm{n}-1)} \cdot \mathrm{kg}^{(1-}\right.$ n). $\mathrm{s}^{-1}$ )

$k^{\prime \prime}$ : reaction rate constant of surface reac- 
tions $\left(m^{3(n-1)+1} \cdot \mathrm{kg}^{(1-n)} \cdot \mathrm{s}^{-1}\right)$

$k_{0}^{\prime \prime}$ : pre-exponential factor of surface reactions $\left(m^{3(n-1)+1} \cdot \mathrm{kg}^{\left.(1-n) \cdot \mathrm{s}^{-1}\right)}\right.$

$n$ : reaction order

$p, q$ : reaction orders (denaturation)

$r$ : correlation coefficient

$R$ : gas constant, $8.314\left(\mathrm{~J} \cdot \mathrm{mol}^{-1} \cdot \mathrm{K}^{-1}\right)$

$R e:$ Reynolds number

$t$ : time (s)

$t_{p}$ : production time (s)

$T$ : temperature $(\mathrm{K})$

$V$ : volume $\left(\mathrm{m}^{3}\right)$

$T$ : residence time $(s)$

\section{ACKNOWLEDGMENT}

The investigations described in this paper have been financially supported by NOVEM (Netherlands Agency for Energy and the Environment).

\section{REFERENCES}

Burton $H(1968)$ Deposits of whole milk in treatment plants: a review and discussion. $J$ Dairy Res 35, 317-330

Burton H (1988) Ultra-High-Temperature Processing of Milk and Milk Products. Elsevier Appl Sci, London, 292-299
Dannenberg F, Kessler H (1988) Reaction kinetics of the denaturation of whey proteins in milk. J Food Sci 53, 258-263

De Jong $\mathrm{P}$, Bouman $\mathrm{S}$, Van der Linden HJLJ (1992) Fouling of heat treatment equipment in relation to the denaturation of $\beta$ lactoglobulin. J Soc Dairy Technol 45, 3-8

De Wit JN, Klarenbeek G (1989) Technological and functional aspects of milk proteins. In: Milk Proteins in Human Nutrition. Proc Int Symp Kiel, Steinkopff, Darmstadt

Dutch Standard NEN 3198 (1984) Determination of the Nitrogen Amount According to Kjeldahl

Dutch Standard NEN 6633 (1990) Determination of the Chemical Oxygen Demand

Fryer PJ (1989) The uses of fouling models in the design of food process plant. J Soc Dairy Technol 42, 23-29

Grandison AS (1988) UHT-processing of milk: seasonal variation in deposit formation in heat exchangers. J Soc Dairy Technol 41 , 43-49

Jeurnink TJM (1989) Distribution and composition of deposit in heat exchangers. In: Fouling and Cleaning in Food Processing (Kessler $\mathrm{HG}$, Lund DB, eds) ICFC III, Prien, Bavaria

Jeurnink TJM (1991) Effect of proteolysis in milk on fouling on heat exchangers. Neth Milk Dairy J 45, 23-32

Lalande M, René F (1989) Fouling by milk and dairy products and cleaning of heat exchange surfaces In: Fouling Science and Technology (Melo L, Bott TR, Bernado C, eds) Kluwer Nato Asi Ser E 145, Amsterdam 